International Journal of Engineering \& Technology, $7(4.34)(2018) 245-247$
SPC
International Journal of Engineering \& Technology
Website: www.sciencepubco.com/index.php/IJET
Research pa

\title{
The Impact of Tax Amnesty on Tax Revenue and Tax Ratio: Case in Indonesia
}

\author{
Diana Sari*, Yati Mulyati \\ Widyatama University, Bandung, Indonesia \\ *Corresponding author E-mail: diana.sari@widyatama.ac.id
}

\begin{abstract}
The development of tax evasion in a country, often the problem solving is done by voluntary disclosure or tax amnesty. Both voluntary disclosure or tax amnesty seem to be a dilemmatic policy between the desire to uphold the rule of law by prosecuting tax smugglers on the one hand by imposing tax amnesty on the other which is viewed from a legal point of view which negates these claims legally. Tax amnesty is a counterproductive action in the tax sanctions system that regulates the waiver of prosecution or reduces or eliminates claims against penalties or fines contained in the provisions of taxation legislation. The positive side of the tax amnesty program is an increase in state revenues from the tax sector. However, an increase in tax revenues is not always followed by an increase in tax ratio.
\end{abstract}

Keywords: tax amnesty; tax revenue; tax ratio; Indonesia.

\section{Introduction}

The Directorate General of Taxes as the body that manages Indonesian taxation has carried out various ways in an effort to increase state revenues from the tax sector. The phenomenon of low state revenues from the existing tax aspects in developing countries, including in Indonesia, does not seem to be triggered only by the low ratio of the number of taxpayers to the population, but also influenced by other dominant factors such as high tax avoidance practices, tax evasion, tax morality, tax compliance, administration complexity, institutional trust, capacity to implement.

The perception that tax evasion tax avoidance is expanding and intensifying extends in developing countries tends to be caused by very mild sanctions and penalties, and on the other hand the lack of law enforcement. Along with this reality, many governments are trying to establish a legal approach to referral by maximizing sanctions and penalties. This theoretical analysis is justified by [12], where very ambitious tax escapes in developing countries can only be reduced by applying high penalties, and to strengthen this, government policy designs are sought to strengthen the optimal use of punishment.

In some countries, aware of the possibility of counterproductive effects of the tax sanctions system, causing the country to adopt a number of provisions governing the release of claims or reducing demands on taxpayers who take the initiative in disclosing their own irregularities. This policy is often referred to as voluntary disclosure or also referred to as tax amnesty.

In the history of taxation in Indonesia, tax amnesty has been carried out three times, based on Presidential Decree No. 5 of 1964 concerning Tax Amnesty, Presidential Decree No. 26 of 1984 concerning Tax Amnesty and the Law of the Republic of Indonesia No. 11 of 2016 concerning Tax Amnesty. However, the tax amnesty in 1984 was considered unsuccessful because the response of taxpayers was low and was not followed by a comprehensive tax administration reform.
According to the Law of the Republic of Indonesia No. 11 of 2016 tax amnesty is the elimination of taxes that ought to be owed, not subject to tax administration sanctions and criminal sanctions in the field of taxation, by disclosing assets and paying ransom as stipulated in this law.

Tax amnesty implementation is expected to increase tax revenue. Which in turn will increase Indonesia's tax ratio. The tax ratio is a benchmark that uses an assessment of tax revenue divided by total gross income. This ratio is often used to indicate the level of success of a country in tax collection. This ratio is usually used as one of the benchmarks or indicators to assess the performance of tax revenues. While, GDP shows national output is an indicator of community welfare. This increase in tax ratio can indicate success in the tax collection process. It shows the higher value of the rupiah that can be collected as tax revenue from each rupiah national output [8].

\section{Literature Review}

Tax revenues are income received by the government, which is derived from the people's tax used for government expenditure. According to [3], tax revenue is a source of revenue that can be obtained continuously and can be developed optimally according to the needs of the government and the conditions of the community. Meanwhile, according to [7], tax revenue is the dominant source of state financing for routine expenditure and development. Comparison of tax revenue to Gross Domestic Product (GDP) or also called the tax ratio basically reflects the amount of tax revenue that can be collected from each rupiah national income (Gross Domestic Product). This ratio is usually used as one of the benchmarks or indicators to assess the performance of tax revenues, given that GDP shows national output is an indicator of public welfare. The increase in this ratio can indicate success in the tax collection process, because it shows the higher value of the rupiah that can be collected as tax revenue from each rupiah national output [5]. 
To increase the Indonesian government's tax ratio, one of them is by applying the tax amnesty policy in the field of taxation. Indonesia has carried out tax amnesty three times in 1964, 1984 and 2016. According to [6], tax amnesty can be applied primarily to certain fields or industrial sectors that can influence the increase in tax ratio with the condition that the readiness of other supporting facilities and infrastructure is fulfilled.

According to Law No. 11 of 2016 concerning Tax Amnesty that Tax Amnesty is the abolition of taxes that ought to be owed, not subject to tax administration sanctions and criminal sanctions in the field of taxation, by disclosing the Property and paying the Ransom as stipulated in this Law. Whereas, in [4] explained that tax amnesty is an opportunity that is given in a limited time to a certain group of taxpayers to pay a certain amount of money as an exemption from liability (including interest and penalties) in relation to the previous tax year without any concern for criminal prosecution.

According to [4], the purpose of tax amnesty is:

1) Increase state revenue in the short term.

2) Improve taxpayer compliance so that it can increase horizontal justice and increase income in the medium term.

The positive side of the tax amnesty program is an increase in state revenue from the tax sector basically taking the state rights that have not / not been paid by the way the taxpayer pays according to his obligations without being subject to any sanctions [4].

\section{Methodology}

This research uses a descriptive method. To support this analysis, survey research was conducted using secondary data obtained from extracting information from various sources, seminar materials, mass media, electronic media, and others and also supported by literature review.

\section{Results and Discussion}

Until now, Indonesia has made three tax amnesty namely in 1964, 1984 and 2016. The following are the historical facts of the enactment of tax amnesty in Indonesia.

\subsection{In 1964}

Indonesia first implemented a tax amnesty policy in 1964. This policy was implemented through Presidential Decree No. 5 of 1964 concerning Tax Amnesty on September 9, 1964. This tax amnesty was carried out on the consideration of the need for large funds for the benefit of the National Revolution and $\mathrm{Na}-$ tional Planned National Development.

Tax Amnesty in 1964, concerning income or capital accumulation obtained before November 10, 1965 which has not been reported in the Notice and which has not been subject to Income Tax, Company Tax or Wealth Tax. Forgiveness at that time did not question the source of income, whether it was the result of corruption, bribes or bribes that were not disclosed.

The method of repayment is done by paying a ransom of $10 \%$ of the total income or capital accumulation that has not been disclosed. For investments in certain fields such as agriculture, plantations, fisheries, mining, manufacturing and transport companies, the ransom rate was reduced to $5 \%$.

Realization of tax revenues in 1963 amounting to Rp. 46,483.70 billion increased by $127.98 \%$ in the year in which this policy was applied to Rp. 105,975.50 in 1964. In 1965 the realization of tax revenues increased by $144.61 \%$ to Rp. $259,221.90$ billion.

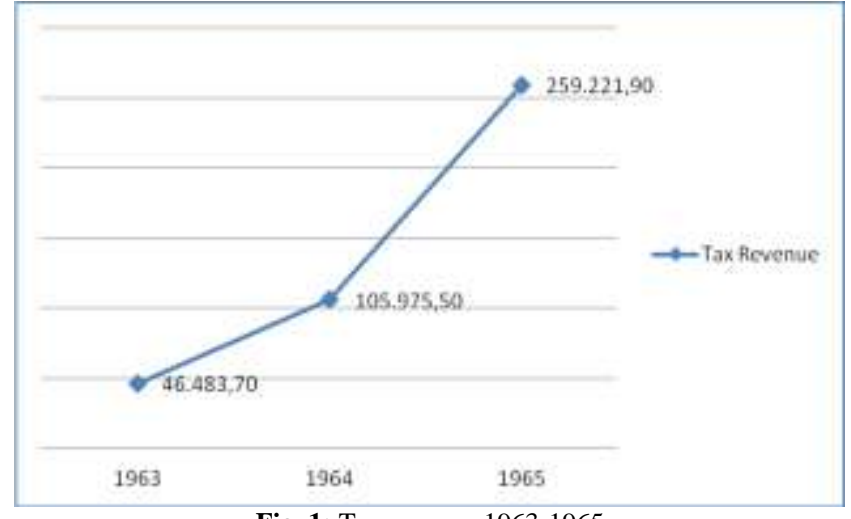

Fig. 1: Tax revenue 1963-1965

The implementation of tax amnesty this year can be said to be unsuccessful in motivating the taxpayers to use this amnesty policy even if seen from the tax revenue before and after this policy is implemented it has increased. The failure to implement tax amnesty in 1964 can be seen in terms of tax ratio. Because before and after this policy is applied, the tax ratio tends to decrease.

In 1963 , the tax ratio of $10.37 \%$ decreased $3.7 \%$ so that the tax ratio in 1964 became $9.98 \%$. A substantial decline occurred one year after this policy which was $45.19 \%$ so that the tax ratio in 1965 was $5.47 \%$. Although tax revenues have increased, the value of Gross Domestic Product (GDP) from 1963 to 1965 also increased. The increase occurred quite large, one year after this policy was implemented. According to [6], the effectiveness of tax amnesty implementation is still low, this effectiveness is measured by the low participation of the tax amnesty participants. Means that, in 1964, there were still many taxpayers who did not comply with the tax amnesty. If the taxpayer is not compliant, it will cause the desire to take action to avoid, smuggle, and tax negligence. So, even though tax revenues have increased but have not been able to attract targeted taxes because there are still many taxpayers who do not participate.

\subsection{In 1984}

The main consideration in the implementation of the amnesty in 1984 was the change in the system adopted from the official assessment to a self-assessment. The object of forgiveness is Income Tax (PPd), Company Tax (PPs), Tax on Interest, Dividend and Royalty (PBDR), Calculating Others' Taxes (MPO), Income Tax Article 17A (PPd 17A), Sales Tax (PPn) and Wealth Tax (PKk) in 1983 and before, which has not been fully charged or collected according to applicable regulations.

The ransom applicable at that time was $1 \%$ from the basis of calculation, for taxpayers who at the date of stipulation of KEPPRES had submitted SPT PPd / PPs in 1983 and PKk in 1984, while for taxpayers who had not fulfilled these provisions, it was applied at a rate of $10 \%$. The basis of calculation is the amount of net assets according to the wealth list / balance sheet on January 1, 1984 minus the amount of net assets listed in the SPT PPd / PPs 1983 and PKk 1984.

The facilities provided for those who make forgiveness, are exempt from fiscal investigation and the wealth report is not used as a basis for investigation and criminal prosecution in any form. The basic alternative calculation can be done with a wealth approach or income approach.

In 1983, the realization of revenue of Rp. 13,913.70 billion decreased by $65.59 \%$ to Rp. 4,788 billion in 1984 . However, one year after this policy was implemented the realization of tax revenue increased by $39.68 \%$ in 1985 to Rp. 6,688 billion. 


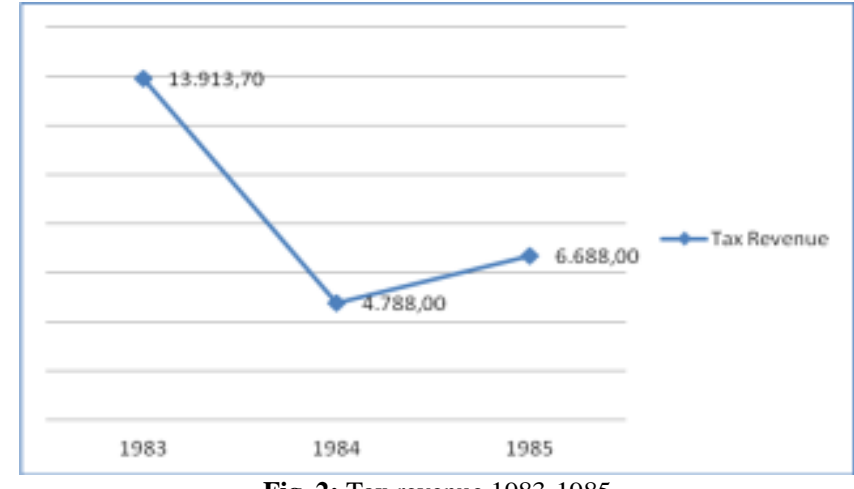

Fig. 2: Tax revenue 1983-1985

According to [6], the implementation of the tax amnesty policy in 1984 was not effective because taxpayers themselves were less responsive and were not followed by reforms in an integrated and comprehensive tax administration system. Likewise, the lack of openness and increased to information access to the public, including the control system of the Directorate General of Taxes themselves.

In 1983, Indonesian taxation experienced Tax Reform which began on January 1, 1984. With the tax reform, Indonesia's tax system changed from the official assessment to self-assessment. Then that became a factor in the failure of the implementation of the tax amnesty policy in 1984 because of the taxpayer's doubts about regulatory issues. The tax amnesty policy in 1984 was not based on the legal umbrella of the act (law).

This considerable decline was due to the 1983 recession of the world recession which resulted in the decline in world oil demand and prices. As a result, the export of oil and gas also declined, which affected the oil and gas company tax because before oil and gas became the prima donna to be a source of tax. To stabilize the economy at that time, the government implemented tax reform in 1983.

The impact of the tax amnesty policy in 1984 on the tax ratio shows a substantial decline in 1983 to 1984 of $70.49 \%$ of the tax ratio in 1983 of 18.88 decreased in 1984 to 5.57. One year after this policy was implemented, in 1985 the tax ratio increased by $26.75 \%$ so that the tax ratio in 1985 became 7.06 . The tax amnesty policy this year is expected to attract non-compliant taxpayers to pay their taxes, but this policy is said to be unsuccessful in attracting non-compliant taxpayers. Because of the tax reform on and the lack of regulation that is strong enough.

\subsection{In 29016}

As already known, the public knows that Indonesia is reimplementing tax amnesty. The legal basis for the application of this policy is through Law No. 11 of 2016 concerning Tax Amnesty. This policy has a time limit, starting on the 1st (1st) July 2016 until March 31, 2017.

Realization of tax revenue in 2015 amounted to Rp 1,240,418.86 billion increased by $24 \%$ to Rp. 1,539,166.20 billion in 2016 and decreased by $3 \%$ in 2017 to Rp. 1,495,893.80 billion.

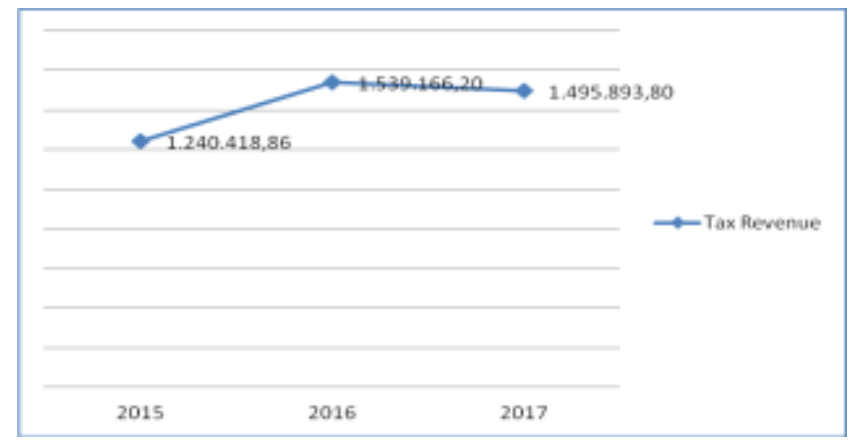

Fig. 3: Tax revenue 2015-2017
In the short term, tax amnesty can increase tax revenue which is useful for Indonesia to finance various programs that have been planned. In the long run, Indonesia will receive acceptance tax from additional economic activity which comes from the property that has been transferred and invested inside Indonesian territory.

Tax Amnesty in 2016 succeeded in increasing tax revenues. However, efforts to increase tax revenue are only temporary (ad hoc). Therefore, when the ad hoc program to increase tax revenue no longer exists, the tax ratio still falls. Efforts to increase tax revenue must be sustainable, so that it will have a positive impact on the tax ratio in the long run.

However, this increase was not followed by a tax ratio in which the tax ratio in 2016 decreased compared to 2015 from 10.9 to 10.4 and the 2017 tax ratio is $10.7 \%$. The tax ratio is not the only measure of the performance of the tax authorities, but these achievements show that the tax collection performance in Indonesia is still not good compared to other countries.

\section{Conclusion}

From the implementation of the tax amnesty policy in Indonesia 3 times namely in 1964, 1984 and in 2016, this has an impact on the economy. Viewed in terms of tax revenue realization and tax ratio, based on the results of this study it can be seen that the realization of tax revenue and tax ratio when the tax amnesty policy is applied tends to increase. This tax revenue can be used as a source of funds for state financing, which is expected to improve the welfare of the community. In addition, the tax ratio tends to increase. This increase can mean that tax revenues also increase with the increase in tax revenue can be used as government expenditure or state expenditure.

\section{References}

[1] Allingham, M. G., \& Agnar, S., 1972. Income Tax Evasion: A Theoretical Analysis. Journal of Public Economics, 1, 323-338.

[2] Becker, G. S., 1968. Crime and Punishment: An Economic Approach. In The Economic Dimensions of Crime. Palgrave Macmillan, 1968, pp. 13-68.

[3] Hutagaol, J., 2007. Perpajakan Isu-Isu Kontemporer. Graha Ilmu.

[4] Muttaqin, Z., 2013. Tax Amnesty di Indonesia. Refika Aditama.

[5] Parmadi, P., 2011. Suatu Deskripsi Tentang Penerimaan Pajak Dalam Negeri Indonesia Periode 1990 - 2007. Jurnal Paradigma Ekonomika, 1(3), 15-26.

[6] Ragimun., 2012. Analisis Implementasi Pengampunan Pajak (Tax Amnesty) Di Indonesia. Kajian Fiskal Badan Kebijakan Fiskal Kementrian Keuangan.

[7] Suryadi., 2006. Hubungan Kausal Kesadaran, Pelayanan, Kepatuhan Wajib Pajak dan Pengaruhnya terhadap Kinerja Penerimaan Pajak : Suatu Survey di Wilayah Jawa Timur. Jurnal Keuangan Publik, 4(1), 105-121.

[8] Wibowo, D., 2013. Pengaruh Pendapatan Per Kapita, Economic Growth Rate, Economic Structure, dan Tax Rate Terhadap Tax Ratio Pada Negara-Negara OECD dan Indonesia. Jurnal Akuntansi Universitas Jember, 11(1), 45-61. 